\title{
Buják-Szente, egy nyílt színi paleolitikus telep
}

\author{
Péntek Attila, Zandler Krisztián
}

Kivonat

\section{Abstract}

\section{Kulcsszavak}

Keywords

Szerző • Author

Hivatkozás • Cite as

Kézirat történet • Article history

Jogok • Copyright (c) $\$$

\begin{abstract}
A Nógrád megyei Buják község határában 2001 óta folyó terepbejárások során felfedezett lelőhelyek közül Buják-Szentéről került elő gazdagabb pattintott kőegyüttes. Ennek nagyobb része a paleolitikumba, kisebb része a fiatalabb őskorba (valószínűleg a neolitikumba) sorolható. A leletanyag döntő többsége helyi nyersanyagból (limnokvarcit és kovakavics) készült, a távolsági nyersanyagok között obszidián és tüzkő szerepel. A paleolitikus együttes, melyben feltűnő a kvarcporfír nyersanyag hiánya, egyértelműen szilánkiparként definiálható. Az eszközkészletben kaparók és vakarók mellett levéleszközök és egyéb bifaciálisan megmunkált darabok találhatók. A tipológiai összkép alapján egy fiatal levélhegyes iparról lehet szó, mely esetlegesen a Szeletien kultúrához kapcsolható. A fiatalabb őskori leletegyüttesre, mely szinte kizárólag helyi limnokvarcitból készült, a pengék a jellemzőek, a változatos eszközkészletben főként vakarókat és különböző módon megmunkált pengéket találunk. Kerámia hiányában a kulturális besorolása bizonytalan, de valószínúleg a lengyeli kultúrába tartozhat.
\end{abstract}

\section{Buják-Szente open air palaeolithic site, Cserhát Mountains, North Hungary}

Since 2001, field walking surveys are undertaken in the vicinity of the village Buják, Nógrád county, Hungary. Among the discovered sites, Buják-Szente provided a rich collection of lithics. The majority of the artifacts belongs to the Palaeolithic period, the younger pieces possibly are from the Neolithic. Most of the artifacts were made of local rocks (limnic quartzite and flint), the long-distance materials are represented by obsidian and northern flint. The Palaeolithic flake industry lacks quartz-porphyry pieces. Side-scrapers, end-scrapers, leaf shaped and other bifacial tools are represented among the tools. The typological character of this collection suggests a younger bifacial industry, which bears a resemblance to the Szeletian culture. The younger lithic sample has a laminar character, it is made almost exclusively of limnic quartzite. End-scrapers and other worked blades dominate the class of tools. In the absence of ceramic sherds, the connotations of these lithics are uncertain, probably they belong to the Lengyel culture.

\section{Cserhát hegység, terepbejárás, limnokvarcit, kovakavics, levéleszköz, paleolitikum, Szeleta kultúra}

Cserhát Mountains, field walking, reconaissance, flint pebbles, leaf shaped tool, Palaeolithic, Szeletian

Péntek Attila, 2143 Kistarcsa, Késmárki u. 27.

Zandler Krisztián, Dornyay Béla Múzeum, 3100 Salgótarján, Múzeum tér 2.

Péntek, A., Zandler, K. (2014) Buják-Szente, egy nyílt színi paleolitikus telep (Buják-Szente, an open-air palaeolithic site). Litikum 2:5-18. https://doi.org/10.23898/litikuma0007

Érkezés | Received: 2014. 06. 09. Elfogadás | Accepted: 2014. 10. 12. Közzététel | Published: 2014. 10. 21.

C Az egyes szerző(k). Ez egy nyílt hozzáférésű publikáció, amit a Creative Commons 4.0 licensze véd. A termék szabadon használható, terjeszthető és sokszorosítható az eredeti szerző és forrás megjelölése mellett. | This is an open-access article distributed under the terms of the Creative Commons Attribution License, which permits unrestricted use, distribution, and reproduction in any medium, provided the original author and source are credited.
2001 óta szisztematikus terepbejárások folynak a Nógrád megyei Buják település tágabb térségében. A terepbejárásokat jelentősen megnehezíti - ugyanakkor nyilvánvalóan kihat azok eredményességére - az a tény, hogy az őskori megtelepedésre alkalmas területek nagy részét jelenleg erdő borítja. Így nem meglepő, hogy ezeknek a terepbejárásoknak a során összesen két, paleolitikus leleteket is szolgáltató településnyomot sikerült lokalizálni. Buják-Nádasd lelőhelyen a terepkutatás ugyan még viszonylag kezdeti stádiumban van, az eddig ott talált régészeti anyag (néhány penge és tompított hátú eszköz) alapján minden valószínűség szerint a felső paleolitikumhoz kapcsolható. A szomszédos Ecseg településhez tartozó Sándor-hegyen, egy nagyobb kiterjedésű őskori lelőhely közelében találtunk néhány kvarcporfír szórványleletet, amelyek közül egy kaparótöredék tipológiailag mindenképpen paleolitikusnak tekinthető. A Markó Andrással 2005 májusában a Buják községtől délkeletre található Rózsás-tető dombháton végzett terepbejárás során talált radiolarit kaparót szintén paleolitikus korúnak tartjuk. A térségben előforduló szórványleletet szolgáltató településfoltok többsége azonban általában fiatalabb óskori kultúrákhoz köthető.

A következőkben a már 2001 óta ismert és nagyobb régészeti anyaggal rendelkező Buják-Szente lelőhelyet ismertetjük. A szóban forgó terület korábban parlagon hevert, a múvelés alá vonás alkalmával mélyszántást végeztek rajta $40-45 \mathrm{~cm}$ mélységben. A lelőhelyen ezt követően 2005-ig volt gyűjthető több-kevesebb pattintott kő, akkor a terület kisebb részén elkerített bodzaültetvényt hoztak létre, nagyobb részén felhagytak a gazdálkodással. A terület jelenleg is elhanyagolt, gazos. A 2007 óta a Magyar Nemzeti Múzeumban található leletanyag feldolgozására csak 2013 január-február hónapok során került sor, s összesen 1495 db a lelőhelyről származó régészeti leletet érintett. A feldolgozás során makroszkopikusan meghatároztuk az egyes felhasznált nyersanyagféleségeket és elvégeztük a régészeti leletek tipológiai 


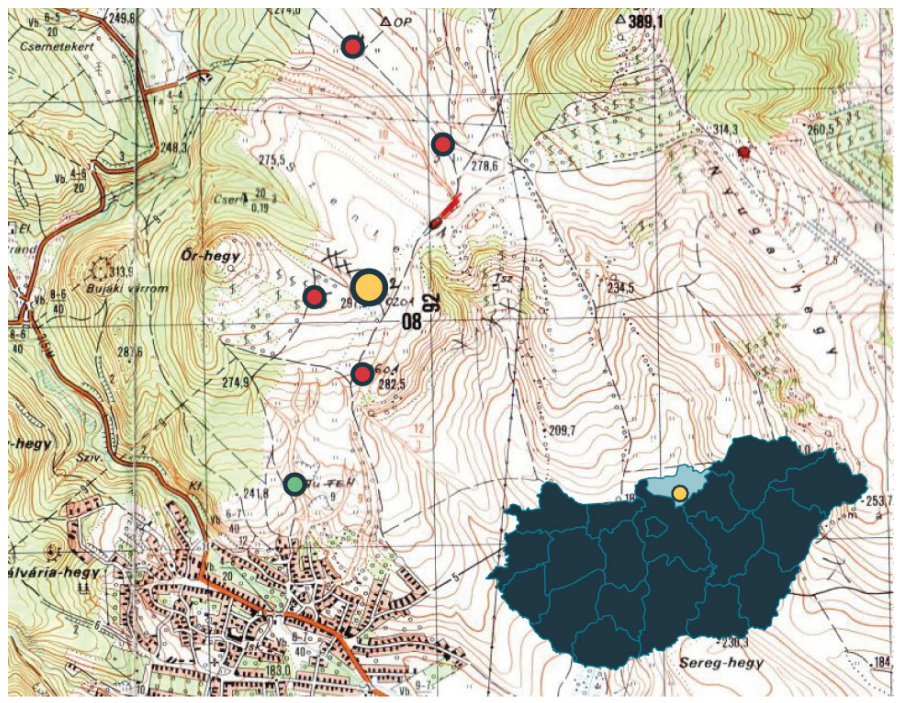

1. ábra. A lelőhely és környezete. Világoskék: Nógrád megye, sárga: Buják-Szente, piros: szórvány leletek, zöld: Buják-Fehér-oldal // Figure 1. Location of the site. Light blue: Nógrád county, yellow: Buják-Szente, red: stray find spots, green: Buják-Fehér-oldal.

alapú vizsgálatát is. A tipológiai vizsgálat során a régészeti anyagban 102 db formális eszközt különítettünk el, amelyek közül $72 \mathrm{db}$-ot tekintünk paleolitikusnak. A további $30 \mathrm{db}$ eszköz fiatalabb őskori, minden valószínűség szerint a lengyeli kultúrába sorolható.

\section{A lelőhely földrajzi leírása}

Buják település a Keleti-Cserhátban található. A Cserháthegység keleti részének kialakulásában a miocén kori andezites jellegú vulkanizmus játszott döntő szerepet. A terület eredetileg a Mátra hatalmas méretű vulkáni felépítményének nyugati peremvidékéhez tartozott, és attól csak később különült el a Zagyva-árok besüllyedésével. Bár magassága átlagosan nem túl nagy, a magasságkülönbségek jelentősek. Felépítésében egyaránt jelentős szerepet játszanak az egykori miocén vulkáni takarók ÉK-DNy-i törések mentén földarabolt, egyenlőtlenül kiemelt, gyakran lépcsők sorozatával elkülönülő nagyobb, összefüggő darabjai, ill. kisebb roncsai. Jellemzőek továbbá a hasadékkitöltések, az andezit telérek kipreparált gerincei, valamint a vulkáni képződmények közti, oligocén-miocén üledékeken kialakult, változó kiterjedésû medencék és jellegzetes rövid, szûk áttörésü völgyek (Noszky 1923; Horváth 2000).

A lelőhely a településtől északra húzódó nagy kiterjedésű, viszonylag sík plató peremén, a 297,2 m tszf. magasságot jelölő magassági ponthoz közel, egy „zsákvölgy” fölött helyezkedik el. Azt a jelenséget, hogy az idősebb, középső paleolitikus, ill. korai felső paleolitikus településfoltok többnyire félreeső mellékvölgyek, gyakran aszimmetrikus átmetszetű „zsákvölgyek“ mentén, leginkább azok végében helyezkednek el, a Cserhát-hegység területén több esetben is megfigyeltük - Legénd-Káldy-tanya (Markó-Péntek 2003-2004), Vanyarc-Szlovácka-dolina (Markó 2007), Szécsénke-KisFerenc-hegy (Péntek-Zandler 2013), Debercsény-Mogyorós (Markó 2009). Hasonló jelenség figyelhető meg az egri Bükkalján Demjén-Szőlő-hegy, Demjén-Hegyeskő-tető és
Demjén-Hegyeskő-bérc esetében (Zandler 2006; 2012). BujákSzente lelőhelytől délre húzódik a Bujáki-patak mély völgye északnyugat-délkelet irányban, nyugatra pedig az Őr-hegyet a bujáki Várhegytől elválasztó mély, szabdalt völgyrendszer található. (1. ábra)

\section{A lelőhely régészeti anyagában található nyersanyagok}

A lelőhelyen makroszkopikusan összesen 7 nyersanyagféleséget sikerült azonosítani. A nyersanyagra vonatkozó százalékos arányokat a teljes, 1495 darab leletet tartalmazó régészeti anyagra adjuk meg. (1-2. táblázat)

\subsection{Helyi eredetűnek tekinthető nyersanyagok}

A helyi és regionális nyersanyagok közül, amelyek vagy magán a lelőhelyen, vagy attól legfeljebb 20 km-re gyüjthetőek, két nyersanyagféleség fordul elő a leletegyüttesben.

A feltételezésünk szerint zömmel helyi eredetű limnokvarcitnak elsöprő a dominanciája: 1433 db (95,85\%). Érdekes módon erre a lokális eredetűnek tekintett limnokvarcit előfordulásra a releváns geológiai szakirodalomban nem történik konkrét utalás. Noszky Jenő a Cserhát-hegység területén található poszt-vulkanikus jelenségek észlelhető nyomaival kapcsolatban elsősorban Püspökhatvant említi, ahonnan van tudomásunk limnokvarcit előfordulásról (Noszky 1914:317; Csongrádi-Balogh, Dobosi 1995). A vulkáni utóhatásokkal röviden foglalkozik a Cserháthegység földtani viszonyait elemző munkájában is (Noszky 1940:100-101). Az 1940-es években Bogsch László tesz említést a Szirák és Bér között húzódó Öreg-hegy déli oldalában meglévő szarmata meszes homokrétegekben található kemény kovásodott mészkőpadokról (Bogsch 1943). A Cserhát hegység limnokvarcit előfordulásaival Markó András foglalkozik részletesebben (Markó 2005).

Ebbe a nyersanyag kategóriába belevettük a kevéssé átkovásodott darabokat is, amely gyakorta a tömbök vagy gumók külső kérgét képezi. Szerkezetében lyukacsosnak, porózusnak látszik, sokszor inkább „átkovásodott vulkáni hamu” benyomását kelti. A limnokvarcit kisebb-nagyobb tömbök, gumók formájában megtalálható a lelőhely területén is, illetőleg annak közvetlen közelében, az Ôr-hegy keleti lábánál. Ez a tömbös, gumós forma többnyire rossz minőségű, sok zárványt, növényi maradványokat tartalmaz. A színe frissen kékes-szürke, sárgás-barna és ezek árnyalatai. Sokkal jobb minőségű, homogénebb szerkezetû, esetenként 8-10 cm vastagságú réteges-táblás megjelenésű limnokvarcitnak a közeli előfordulási helyét ismerjük terepbejárásainkból (Bujáktól délre a Körtefa-tábla oldalban és a Rózsás-tető dombháton) (Markó 2005:54). A lelőhelyen magkő, ill. magkő-kezdemény (pre-core) formájában több darab is található, ezek vastagsága azonban mindössze 3-4 cm. Hasonlóan jó minőségú rétegestáblás limnokvarcit van a lelőhelytől délnyugatra, mintegy 6 kilométerre fekvő Bér-Egresi-dúlőben is. Az itt található, mühely jellegú lelöhely részben paleolitikus régészeti leletanyaga még publikálatlan. (2. ábra)

Egyetlen limnokvarcit darab, egy (pszeudo-)véső (ltsz.: 61) esetén merült fel a nyersanyag mátrai eredete. Ez a kőzet 


\begin{tabular}{|c|c|c|c|c|c|c|c|c|c|}
\hline Leletek / Nyersanyag & $\begin{array}{r}\text { Limnokvarcit } \\
\text { Limnic quartzite }\end{array}$ & $\begin{array}{r}\text { Kovakavics } \\
\text { Silex }\end{array}$ & $\begin{array}{l}\text { Andezit } \\
\text { Andesite }\end{array}$ & $\begin{array}{r}\text { Kvarcit } \\
\text { Quartzite }\end{array}$ & $\begin{array}{c}\text { Obszidián } \\
\text { Obsidian }\end{array}$ & $\begin{array}{r}\text { Radiolarit } \\
\text { Radiolarite }\end{array}$ & $\begin{array}{r}\text { Túzkő } \\
\text { Flint }\end{array}$ & $\begin{array}{r}\text { Összesen } \\
\text { Total }\end{array}$ & $\begin{array}{r}\text { Százalék } \\
\text { Percent }\end{array}$ \\
\hline Eszközök / Tools & 92 & & & 1 & 1 & 5 & 3 & 102 & 6,82 \\
\hline Magkövek / Cores & 37 & 2 & & & & 2 & & 41 & 2,74 \\
\hline Pengék ( $h>=2 *$ sz) / Blades $\left(I>=2{ }^{*} w\right)$ & 33 & & & & & & 1 & 34 & 2,27 \\
\hline Szilánkok (> 20 mm) / Flakes (> 20 mm) & 317 & 2 & 2 & & 2 & 7 & & 330 & 22,07 \\
\hline Szilánkok (<20 mm) / Flakes (< 20 mm) & 231 & & & & 2 & 7 & & 240 & 16,05 \\
\hline Ütőkövek, csiszolókövek / Hammerstones & & & 2 & & & & & 2 & 0,13 \\
\hline Nyersanyagdarabok, törmelék / Chunks & 723 & 11 & & & 2 & 10 & & 746 & 49,90 \\
\hline Összesen / Total & 1433 & 15 & 4 & 1 & 7 & 31 & 4 & 1495 & \\
\hline Százalék / Percentage & 95,85 & 1,00 & 0,27 & 0,07 & 0,47 & 2,07 & 0,27 & & 100,00 \\
\hline
\end{tabular}

\begin{tabular}{|c|c|c|c|c|c|c|c|c|c|}
\hline Leletek / Nyersanyag & Limnokvarcit & Kovakavics & Andezit & Kvarcit & Obszidián & Radiolarit & Túzkő & Összesen & Százalék \\
\hline Vakarók / End-scrapers & 14 & & & & & 2 & 1 & 17 & 23,61 \\
\hline Levéleszközök / Leaf shaped tools & 5 & & & & & & & 5 & 6,94 \\
\hline Kaparók / Side-scrapers & 22 & & & 1 & 1 & 1 & & 25 & 34,72 \\
\hline Bifaciális eszközök / Bifacial tools & 5 & & & & & & 1 & 6 & 8,33 \\
\hline Egyéb eszközök / Miscellaneous tools & 17 & & & & & 2 & & 19 & 26,39 \\
\hline Összesen / Total & 63 & & & 1 & 1 & 5 & 2 & 72 & \\
\hline Százalék / Percentage & 87,50 & 0,00 & 0,00 & 1,39 & 1,39 & 6,94 & 2,78 & & 100,00 \\
\hline
\end{tabular}

„márványos, mozaikos” jellegű, amelynek a Cserhát-hegységben való geológiai előfordulása jelenlegi ismereteink alapján nem igazolható, bár régészeti anyagban pl. Legénd-Rovnya lelőhelyen is megtalálható (Péntek-Zandler sajtó alatt).

A 15 db kovakavics, amelynek aránya 1,00\%, feltehetően ugyancsak helyi eredetűnek tekinthető. A leletanyagban csak 2-2 db magkő illetve szilánk, továbbá 11 nyersanyagdarab, törmelék fordul elő kovakavicsból, megmunkált darab nem. Noszky Jenő megemlíti az „alsó szármáciai és alsó-pannóniai képződmények között elhelyezkedö, homokos-kavicsos terresztrikumok" jelenlétét a környéken (Noszky 1940:119). A legközelebbi lehetséges forrásként a lelőhelytől északra mintegy 3-4 kilométer távolságra, Bokor és Cserhátszentiván települések között található kavicságyak említhetők. Ezek geológiai kora a régi nevezéktanban „alsó pliocén szarmata emelet” (Noszky 1940:114), az új neogén rétegtani nevezéktani elnevezése „felsô miocén szarmata emelet Kozárdi Formáció" (Hámor 1985:265). Egy további lehetséges forrásként a limnokvarcit kapcsán fentebb megemlített Bér-Egresi-dúlő nagy kiterjedésű kavicságya jöhet szóba. Itt jelentős mennyiségű kovakavics, numuliteszes kovakavics is található. Ezek geológiai kora a régi nevezéktanban „alsó pliocén magasabb szarmata-terresztrikum" (Noszky 1940:116), az új neogén rétegtani nevezéktani elnevezése „felsô miocén Szarmata emelet Sajóvölgyi Formáció" (Hámor 1985:262).

Az 1 db kvarcit kavics aránya 0,07\%. Ez az egyetlen darab egy atipikus, ívelt élü egyszerü kaparó. Forrása minden bizonynyal a kovakavics nyersanyag származási helyével kapcsolatban említett valamelyik nagyobb kiterjedésü kavicságy lehet.

\subsection{Távolsági nyersanyagok}

Az 50 km-nél messzebbről származó nyersanyagféleségeket soroltuk ebbe a kategóriába. A régészeti leletanyagban a távolsági nyersanyagok közül 7 db (0,47\%) obszidián található. Valamennyi darab átlátszó, fekete, kárpáti 1-es típus, amely Kelet-Szlovákiában a Zempléni-szigethegységben fordul elő (T. Biró 1981:194; 1984:47). Az egyetlen obszidián eszköz egy egyenes élü egyszerü, természetes hátú kaparó (ltsz.: 38; 3.2. ábra) egyértelmúen középső paleolitikus, ill. korai felső paleolitikus jelleggel bír, a további darabok szilánkok.

Feltételesen tűzkőként határoztuk meg 4 db lelet (0,27\%) nyersanyagát. A tűzkő szerves vagy szervetlen eredetű, különböző kristályszerkezetû kvarcváltozatok gyűjtőneve. Kréta kori mészkőben, gumók, gömbök formájában fordul elő. Tömör, kagylós törésű. Felszínét régészeti környezetben gyakran borítja fehér patina, ilyenkor pontos származási helyük beazonosítása lehetetlen. Nagy valószínüséggel Sziléziából, kb. 300 km távolságról kerülhettek a lelőhelyre (T. Dobosi 1978:12-14; T. Biró 1984:51-52; 2011:213-215). Feltevésünk szerint a leletek közül 1 db szilánkvakaró (ltsz.: 3; 3.7. ábra) és 1 db bifaciális eszköz (ltsz.: 15) tipológiailag inkább a paleolitikus régészeti anyaghoz kapcsolódik. A tűzkő mint nyersanyag a Cserhát hegységben található régészeti lelőhelyeken csak szórványosan fordul elő. A belőle készített eszközökre minden esetben jellemző az igen finom, gondos megmunkálás.

\subsection{Ismeretlen eredetű nyersanyagok}

A vulkanikus eredetű andezit mint nyersanyag 4 db lelet ( 2 db szilánk, 1 db ütőkő és 1 db csiszolókő) formájában van jelen (0,27\%). Szerkezetében finom szemcsés, világosszürke, penészszürke mállási kéreggel fedett változat, viszonylag jól pattintható. Hasonló tulajdonságú andezit található a Galgagyörktől keletre húzódó Megyerke-völgy bányáiban (Szentes 1943:8). A Noszky Jenő leírása alapján tett geológiai terepbejárásaink során Alsótold-Bableves csárda fölötti platón is 


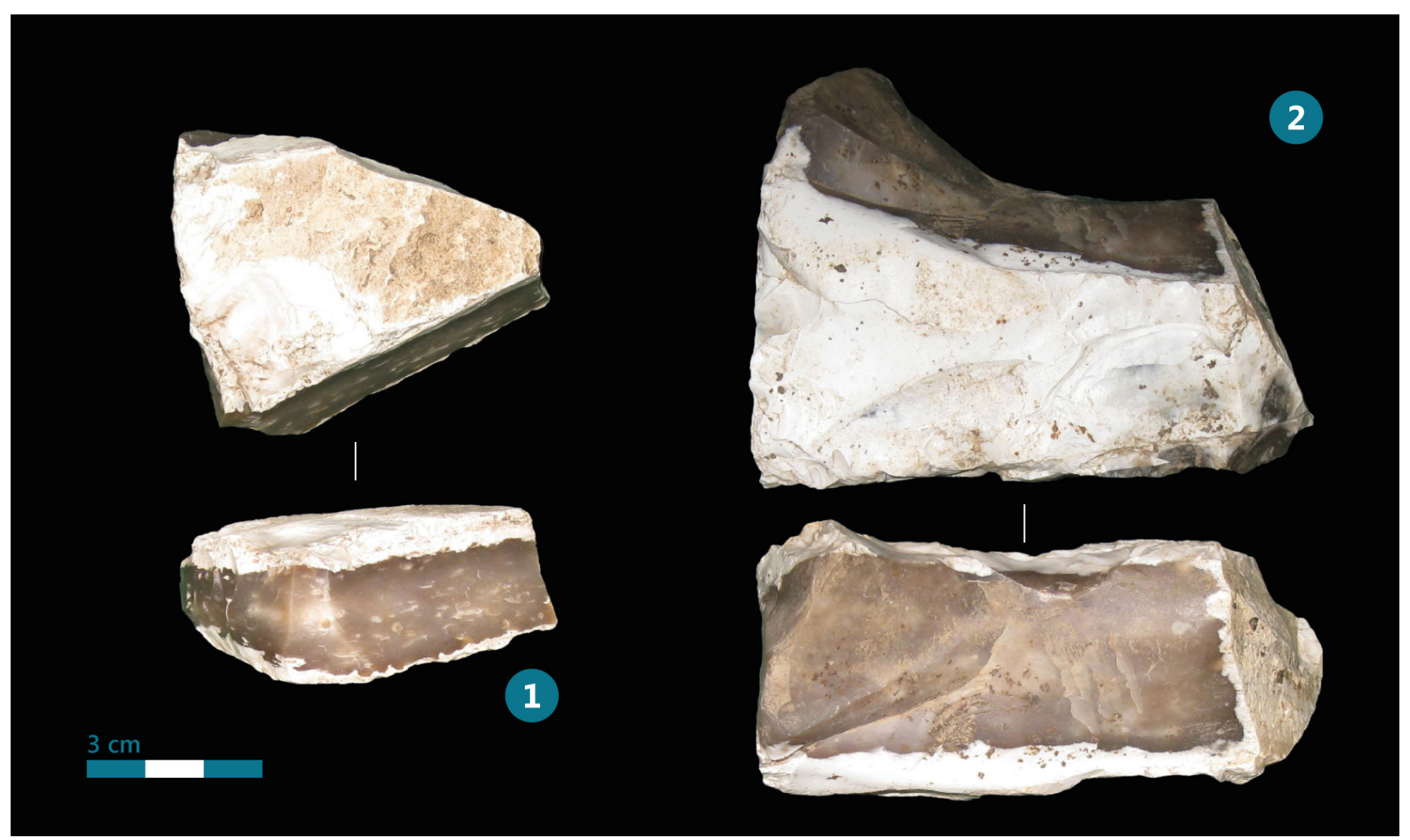

2. ábra. Réteges-táblás megjelenésű limnokvarcit darabok a lelőhelyről. // Figure 2. Tabular limnic quartzite blocks from Buják-Szente. Fotók: // Photos: Zandler K.

találtunk pattintásra alkalmas andezitet(Noszky 1914:314-317). Az andezit előfordulása a Cserhát-hegység paleolitikus lelőhelyein, ha nem is nevezhető általánosnak, de jól ismert tény. Nagyobb mennyiségben Galgagyörk-Csonkás-hegy lelőhelyen fordul elő (Markó 2004:10). Egy Hont-Csitár lelőhelyről származó levélkaparót említ Zandler Krisztián (Zandler 2010:26). Az andezit megtalálható egyes Eger környéki lelőhelyek régészeti anyagában is (Zandler 2012). Az andezitnek mint nyersanyagnak a felhasználását említi a Gyöngyös környéki régészeti anyagokkal kapcsolatban Gutay Mónika is (2007:130). Az andezit kérdéssel átfogóan foglalkozik Markó András doktori disszertációjában, amelyben a Nógrád megyei Vanyarc település környékén található középső paleolitikus jellegű lelőhelyek régészeti anyagát elemzi (Markó 2012:25).

Nem ismerjük pontosan a $31 \mathrm{db}(2,07 \%)$ radiolarit származási helyét. A radiolarit szerves eredetû jura kori kovakőzet, kovavázú szervezetek (radioláriák) vázrészeiből halmozódik fel, feltehetően többszöri oldódás és kicsapódás után. Általában karbonát kőzetekbe beágyazva, kisebb-nagyobb gumók alakjában jelenik meg (T. Dobosi 1978:12; T. Biró 1984:48-49). A Börzsöny keleti oldalán a Nagyoroszi Formációból kavicsformában is ismert (Markó-Péntek 2007:174). Az általunk ismert cserháti nyersanyaglelőhelyeken korlátozott mennyiségben ugyan, de általánosan előfordul pattintásra alkalmas, kisebbnagyobb kavics formájában. A sötétbarna, bordó változatok dominálnak (14 db) a zöldes-szürke (4 db) felett. A $4 \mathrm{db}$ világosbarna, 3 db sárgásbarna, 2 db okkersárga, 1 db barnás, a Cserhát-hegységben ritkán vagy egyáltalán nem előforduló színváltozatok. Egy vöröses színű lelet esetében elképzelhető, hogy tulajdonképpen jáspis. Az 5 darab radiolarit eszköz (2 db szilánkvakaró, 1 db kaparó, 1 db völgyelt eszköz, 1 db szilánk) tipológiailag a paleolitikus régészeti anyaghoz kapcsolódik. Nem kizárt, hogy az esetlegesen dunántúli eredetû radiolarit egy része fiatalabb őskori, ez a feltevés azonban tipológiailag nem igazolható, mert eszköz nem fordul elő belőle.

\section{A paleolitikus régészeti leletanyag}

A paleolitikus kőanyaggal kapcsolatban kevés technológiai megfigyelés tehető. Egyértelműen szilánkiparról van szó. Laminaritás szinte nem létezik, a leletanyagban összesen 1 db penge található. A Levallois-debitázsnak nincsen nyoma, jellemző a bifaciális megmunkálás intenzív alkalmazása, amely legalább 12 db eszköz esetén megfigyelhető. Az alkalmazott debitázsra megfelelő számú és állapotú magkő hiányában nem lehet következtetni. Ugyanezen megállapítások tehetőek a cserháti levéleszközös paleolitikus lelőhelyek jó részén, így Legénd-Rovnya anyagával kapcsolatban is (Péntek-Zandler sajtó alatt).

\subsection{Retusált eszközök}

Az összesen 102 darab formális eszköz tipológiailag szinte egyértelmúen szétválasztható egy régebbi, archaikusabb, paleolitikus régészeti anyagra (72 db) és egy fiatalabb, feltehetően őskori régészeti anyagra (30 db). Ebben a szétválasztásban egyáltalán nem játszott szerepet az eszközök patinásodottsági foka. Ennek a helyi limnokvarcitnak - hasonlóan a mátrai, avasi és egyéb eredetú limnokvarcithoz - az a sajátossága, hogy még hasonló geológiai viszonyok között is egyenetlenül patinásodik. Gyakori jelenség a lelőhelyen, hogy a tipológiailag nyilvánvalóan régi darabok is szinte 

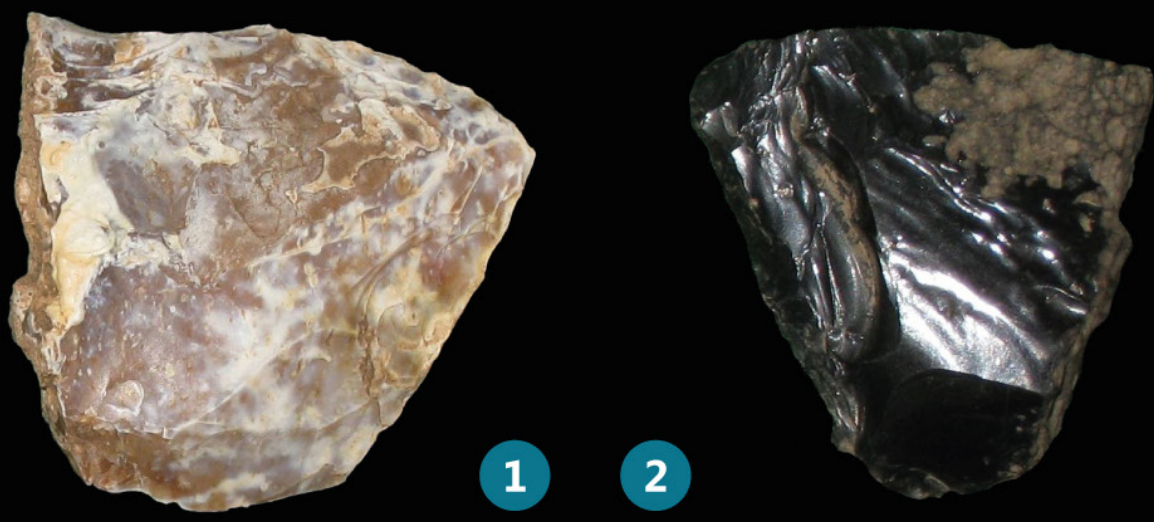

3

4
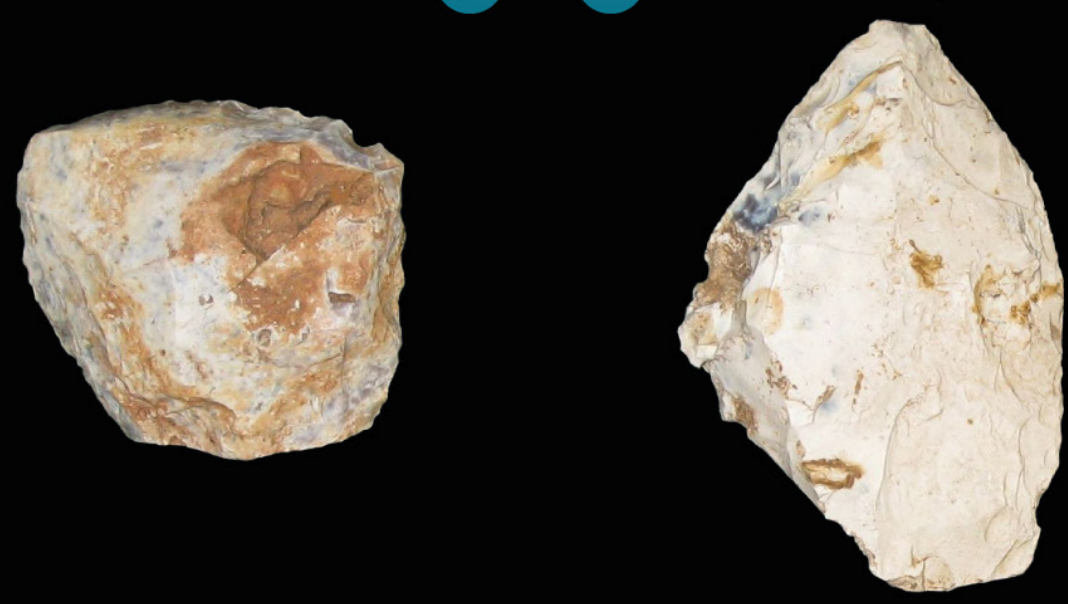

$3 \mathrm{~cm}$

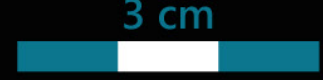

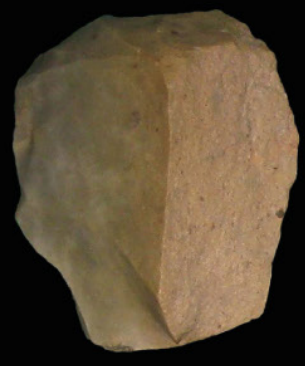

5

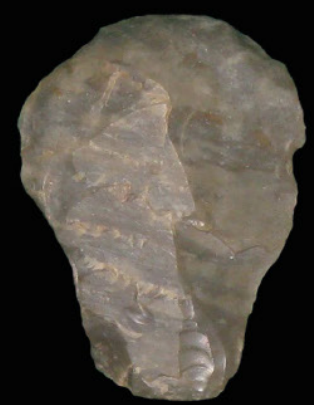

6

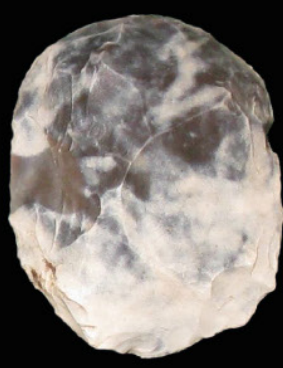

7

3. ábra. 1 - 4: kaparók (Itsz:: 45, 38, 12, 40); 5 - 7: vakarók (Itsz.: 1, 2, 3). // Figure 3.1 - 4: side-scrapers (inv. n.: 12, 40, 45, 38); 5 - 7: end-scrapers (inv. n.: 1, 2, 3). Fotók: // Photos: Zandler K. 


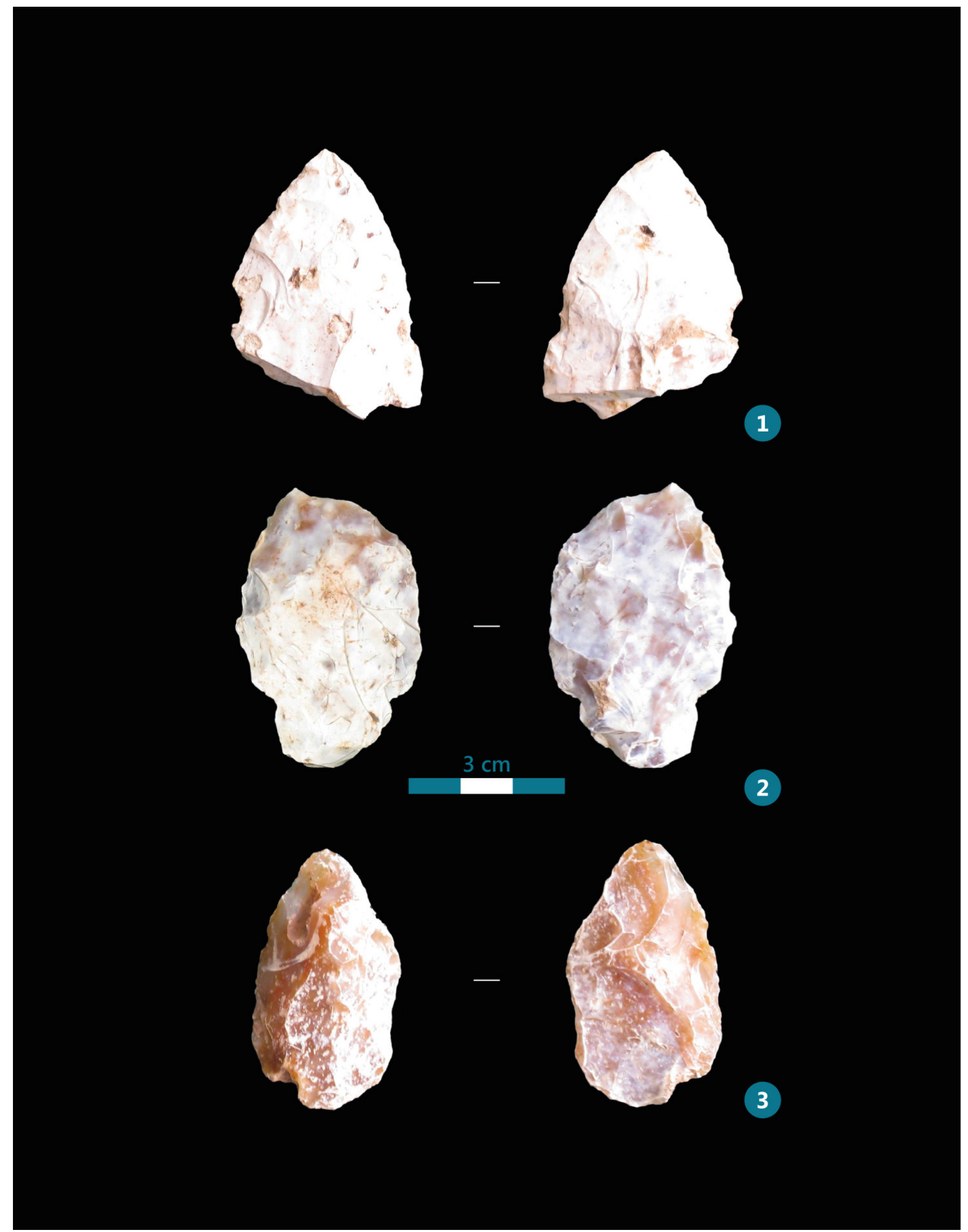

4. ábra. 1: levélhegy előlap és hátlap (Itsz.: 37); 2 - 3: bifaciális eszközök előlap és hátlap (Itsz.: 34, 32) // Figure 4. 1: leaf shaped bifacial tool, dorsal and ventral views (inv. n.: 37); 2 - 3: bifacial tools, dorsal and ventral views (inv. n.: 34, 32). Fotók: // Photos: Zandler K. 


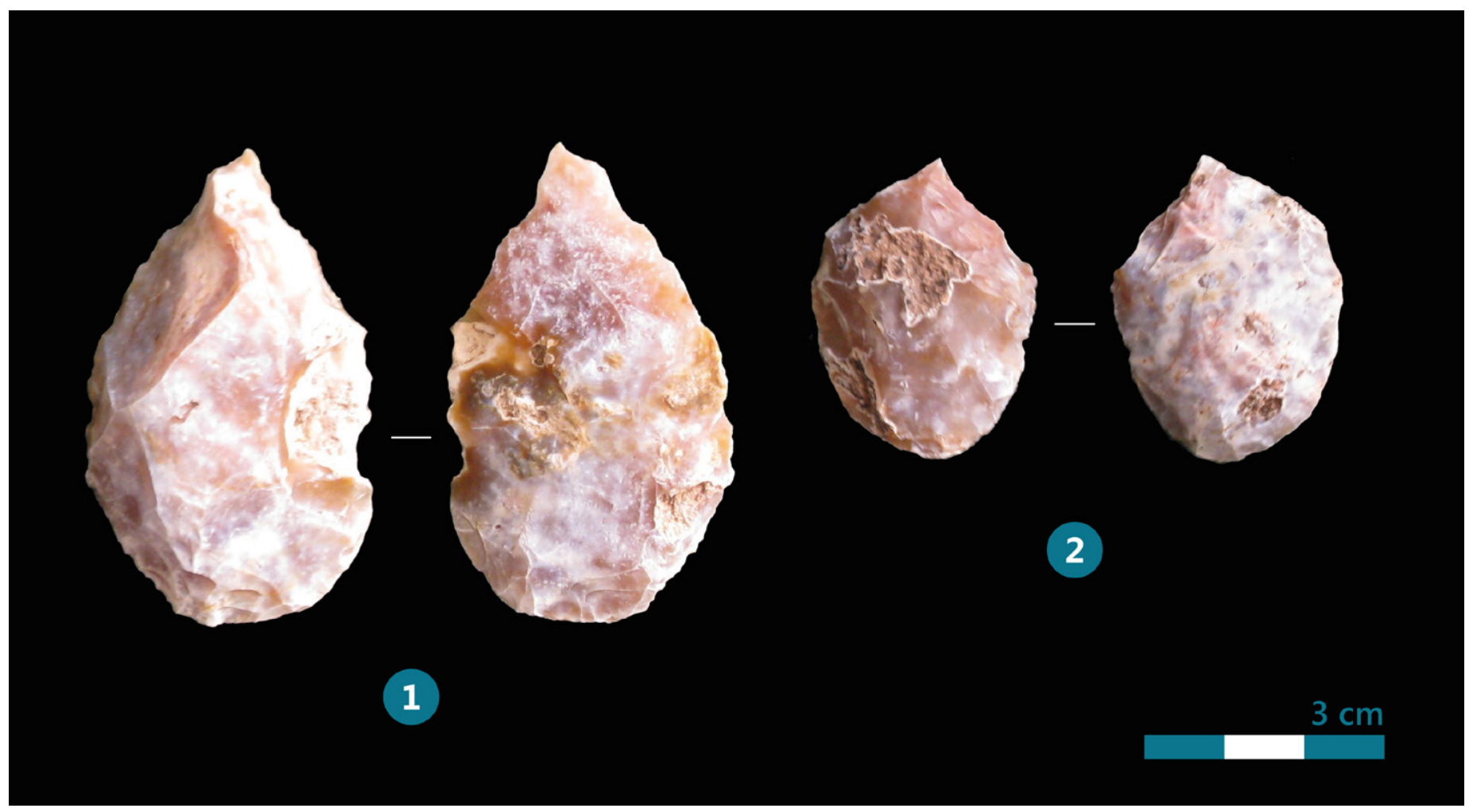

5. ábra. Egyéb eszközök (Itsz.: 1 - 43, 2 - 7). // Figure 5. Other artefacts (inv. n.: 43, 7). Fotók // Photos: Zandler K.

frissnek hatnak. Az eszközökön belül 5 alapvető csoport különíthető el: vakarók, levéleszközök, kaparók, bifaciális eszközök és egyéb eszközök.

\subsubsection{Vakarók}

Összesen $17 \mathrm{db}$ vakarót találunk a régészeti leletanyagban, ez az eszközök 23,61\%-a. Jelentős a nyersanyag-preferencia, ugyanis a $2 \mathrm{db}$ radiolarit (ltsz.: 1, 2; 3.5-6. ábra), és $1 \mathrm{db}$ tüzkő (ltsz.: 3; 3.7. ábra) kivételével valamennyinek a nyersanyaga limnokvarcit. Csak szilánkvakarókat tartalmaz a gyưjtemény. A vakarók között 3 db hajógerinc alakú (ltsz.: 1, 4, 10), $1 \mathrm{db}$ atipikus hajógerinc alakú (ltsz.: 44) és $1 \mathrm{db}$ atipikus orros (ltsz.: 62) vakaró képviseli az felső paleolitikus típusokat. Az 1 db kettős vagy szubcirkuláris vakaró (ltsz.: 3; 3.7. ábra) mellett $1 \mathrm{db}$ atipikus kombinált eszköz (szilánkvakaró+kaparó) (ltsz.: 6) is található a leletanyagban. Viszonylag gyakori az oldalél(ek) retusálása (ltsz.: 2, 5, 6, 10, 11, 25, 44, 62) és előfordul a hátlapi vékonyítás és/vagy a bulbus eltávolítása is (ltsz.: 1, 3, 6, 11). Ezek a jelenségek jól ismertek a morvaországi Szeletien kultúrába tartozó lelőhelyeken, Neslovice (Valoch 1973:13, Tab. I: 2, 4), Ondratice (Valoch 1967:7; Tab. I: 3, Tab. III: 2, 3), Vedrovice V (Valoch 1993:35, 49, Abb. 14: 12, Abb. 28: 1), Trboušany (Hladíková 2002:78, Obr. 9: 3, 4, 7) és a bajorországi Zeitlarn régészeti anyagában is (Schönweiss-Werner 1986:10, Abb. 3:8; Heinen-Beck 1997:84, Abb. 7:5, 6). Megtalálhatóak továbbá az általunk ugyancsak Szeletien kultúrába sorolt Szécsénke-Kis-Ferenc-hegyen is (Péntek-Zandler 2013). A hátoldali vékonyítást megtaláljuk ugyanakkor a korábban publikált Micoquien-Bábonyien jellegú cserháti lelőhelyeken is, így Galgagyörk-Csonkás-hegyen (Markó et al. 2002: Fig. 2: 1, 4) és Legénd-Káldy-tanyán is (Markó-Péntek 2003-2004: Fig. 4: 7), továbbá Szécsénke-Kis-Ferenc-hegyen
(Péntek-Zandler 2013) és Legénd-Rovnya lelőhelyen (Péntek-Zandler sajtó alatt).

\subsubsection{Levéleszközök}

5 db leletet soroltunk ebbe az eszköztípusba (6,94\%). Valamennyinek a nyersanyaga limnokvarcit. Egyetlen töredékes darab (ltsz.: 37; 4.1. ábra) tekinthető levélhegynek. Az erősen patinás felszíne miatt nem állapítható meg egyértelműen, de inkább disztális töredékről lehet szó. Paralelogramma keresztmetszetü, a hossztengelyre szimmetrikus. A jobb oldalél az előlap felől finoman, a hátlap felől laposan retusált, a bal oldalél zegzugos lefutású. Érdekes a 34-es leltári számú lelet (4.2. ábra), amely szinte az előlap teljes felületén centripetálisan megmunkált. Az élek elnagyoltak, a hátlapon laposan retusáltak. Plánkonvex keresztmetszetú, a hossztengelyre aszimmetrikus. A két proximális töredék egyike, a 47-es leltári számú darab mintha későbbi újraretusálást mutatna. Mindkét oldaléle zegzugos vonalú, bifaciálisan megmunkált. Bázisa csonkított, bulbusa nincsen; disztális végén frissebb, nem patinás törés van, amelyen retusált völgyelés található. A 32-es leltári számú lelet hossztengelyre enyhén aszimmetrikus plánkonvex keresztmetszetú, lekerekített bázisú, bal élén zegzugos lefutású, jobb élén hátlapi vékonyítású levéleszköz. Minden valószínúség szerint pattintási hiba miatt felhagyott eszköz (4.2. ábra).

\subsubsection{Bifaciálisan megmunkált eszközök}

$6 \mathrm{db}$ leletet soroltunk ebbe az eszköztípusba (8,33\%). Nehezen klasszifikálható, bifaciálisan megmunkált darabok. Egyetlen tűzkőből készült darab kivételével (ltsz.: 15) valamennyinek a nyersanyaga limnokvarcit. A többség valamilyen töredék, valamennyi egyedi darab. 


\subsubsection{Kaparók}

A legszámosabb eszközcsoportot a 25 darab kaparó alkotja (34,72\%). Nagyon jelentős a nyersanyag-preferencia: $1 \mathrm{db}$ kvarcit, 1 db obszidián és 1 db radiolarit kaparó mellett a többinek a nyersanyaga limnokvarcit. A helyi nyersanyagnak köszönhetően jellemző a viszonylag nagyobb szupport-szilánk felhasználása. A legkisebb töredékes kaparó (26)x(48)x15 mm. A limnokvarcit nyersanyagból készült legnagyobb kaparó méretei: 59x37x15 mm. De nem ritkák a 40 mm-nél hoszszabb töredékek sem. Igen sok (11 db) a töredékes, elsősorban a hosszában törött darab. A kaparók morfológiailag eléggé változatos képet mutatnak. Többségük egyszerü, egyenes élü (5 db), illetve ívelt élü (5 db) kaparó. Az anyagban található 6 db kettős kaparó, 3 db szegletes kaparó, továbbá 1 db bifaciális élmegmunkálású darab. 6 db kaparó atipikusnak mondható. Természetes hátú kaparó (racloir à dos naturel) 4 db található az anyagban (ltsz.: 31, 38, 42, 66). Technológiai szempontból feltétlenül említésre érdemes a 36-os leltári számú darab, amelynél az előlap felszíne teljes felületén megmunkált. A hátlap részlegesen vékonyított, a bulbusát eltávolították. A bal oldalél a hátlap felól vékonyított, a jobb oldalél disztális végén a hátlapon Prondnik-leválasztás. Ez a technika elsősorban lengyelországi középső paleolitikus Micoquien iparok bifaciális megmunkálású késeinek a jellegzetessége, előfordul azonban a németországi Buhlen-barlang IIIb rétegének ugyancsak Micoquien jellegû régészeti anyagában kaparók esetén is (Jöris 2001:32 „Pradnik-Schaber”, Abb. 4.15, 4.16: 1, 3-5, 7-11, 4.17: 1-2). Szórványosan megtalálható a cseh-morva Szeleta iparban is Jezeřany I. és II. lelőhelyeken is (Oliva 1979:48). A Cserhát-hegység paleolitikumában eddig 2 példát ismerünk a Prondnik-leválasztás alkalmazására: SzécsénkeKis-Ferenc-hegy lelőhely anyagában egy bifaciális kést (Péntek-Zandler 2013:41) és Legénd-Rovnya lelőhelyen, eléggé szokatlan módon, egy vakarót (Péntek-Zandler sajtó alatt) (3.1-4. ábra).

Mindenképpen figyelemreméltó a leletanyag egyetlen kvarcit lelete, amely egyszersmind egy viszonylag elnagyolt megmunkálású eszköz, egy atipikus, ívelt élü egyszerú kaparó. Az eszköz szupportja egy nagyméretü kavicsszelet, amelynek eredeti kavicskérge természetes hátat alkot. Méreteivel a teljes eszközkészlet legnagyobb darabja: 66×53×26 mm.

\subsubsection{Egyéb eszközök}

Összesen 19 db leletet, eszközt és azonosíthatatlan eszköztöredéket, megmunkált darabot soroltunk ide (26,39\%). Itt is nagyon jelentös a nyersanyag-preferencia: $2 \mathrm{db}$ radiolarit mellett a többinek a nyersanyaga limnokvarcit. Az eszközök között 2 db tulajdonképpeni kombinált eszköz mellett (ltsz.: 7, 22), 1 db fúró (ltsz.: 43; 5.1. ábra) és 1 db völgyelt eszköz (ltsz.: 48) található. A 7-es leltári számot viselő eszköz (5.2. ábra) előlapjának teljes felülete a középső részén található kisebb zárványtól eltekintve megmunkált. Mindkét oldaléle bifaciálisan retusált, bal oldaléle ívelt, jobb oldaléle tört vonalú. Disztális vége csúcsos, a hátlap felől elvékonyított, a csúcs kétoldali retusált völgyeléssel és vésőpattinték által fúrószerúen kialakított. A 22-es leltári számú eszköz jobb oldaléle retusált, proximális végén vésônegatív, bázisa szándékosan törött vagy csonkított. A 43-as leltári számú eszköz (5.1. ábra) proximális vége mindkét lapon lépcsősen megmunkált. Disztális végén a fúró- vagy lyukasztóhegy kétoldali völgyeléssel kialakított. Bal oldaléle megközelítóleg egyenes vonalú, finoman retusált, jobb oldalélének középső része kitörött, egyébként finoman retusált. A 48-as leltári számú lelet vaskos szilánkon készült atipikus völgyelt eszköz. Disztális vége kéreggel fedett, a bal oldalél bázis felöli része ívesen retusált. Jobb oldalélének bázis közeli része retusált, ill. völgyelt. Az egyéb eszközök között 1 db retusált szilánk vagy ívelt élü kaparó töredéke és $1 \mathrm{db}$ pengén kialakított (pszeudo-)véső értelmezhető még (ltsz.: 61). Ez utóbbi lelet nyersanyaga esetlegesen mátrai eredetû. A többi megmunkált töredék nem alkalmas tipológiai meghatározásra.

\section{A fiatalabb őskori régészeti leletanyag}

A fiatalabb őskori, feltehetően neolitikus leletanyagra egyértelmûen a pengedebitázs jellemző. Az $1 \mathrm{db}$ pengevakaró mellett összesen $10 \mathrm{db}$ penge, illetve mikropenge (lamella) található a régészeti anyagban. Egyetlen kettős vakaró készült tűzkőből, a többinek a nyersanyaga limnokvarcit.

\subsection{Retusált eszközök}

Ebben a régészeti anyagban 30 db eszköz található. Az eszközösszetétel eléggé változatos, a szilánkvakarók mellett pengevakaró, völgyelt és fogazott eszköz, véső és különböző módon megmunkált (retusált, völgyelt) pengék, mikropengék alkotják.

\subsection{Magkövek}

A leletanyagban található 41 db magkő többsége a fiatalabb őskori régészeti anyaghoz kapcsolódik. Közülük $37 \mathrm{db}$ limnokvarcit és mindösszesen $2 \mathrm{db}$ kovakavics. A magkövek a legkülönbözóbb stádiumban maradtak meg: találhatunk számos magkő-kezdeményt (pre-core) (9 db), felhagyott és kimerült magkövet is. A leggyakoribb forma a többirányú (esetenként ortogonális) magkő (20 db), emellett 4 db unipoláris magkő és $1 \mathrm{db}$ bipoláris magkő található a leletanyagban. A további 5 db magkövet nem sikerült klasszifikálnunk, ezek között azonban legalább 3 db nagyobb méretű szilánkon készült, valószínúleg paleolitikus korú található. A magkövek között összesen $5 \mathrm{db}$ a penge-, mikropenge(lamella)magkő, a többi darab állapotától függetlenül (felhagyott, kimerült) kivétel nélkül szilánkmagkő benyomását kelti. (6. ábra)

\section{5. Összefoglalás}

Szembeötlő a lelőhely múhely jellege, a leletek 88,16\%-a debitázsanyag, ill. nyersanyagdarab és törmelék. A leletanyag tipológiailag kevert jellege nyilvánvaló, legalábbis két kronológiai horizont anyagával számolhatunk.

Az eszközök nagyobb része paleolitikus, tipológiailag viszonylag homogén. Jóllehet aránylag kevés eszköz (összesen $72 \mathrm{db}$ ) képviseli csupán a paleolitikus ipart - és ez a körülmény mindenképpen megnehezíti az értékelését -, véleményünk szerint egy fiatal levélhegyes, esetlegesen a Szeletien kultúrához kapcsolható leletanyaggal van dolgunk. Ami a Cserhát hegységben található levéleszközös lelőhelyeken 


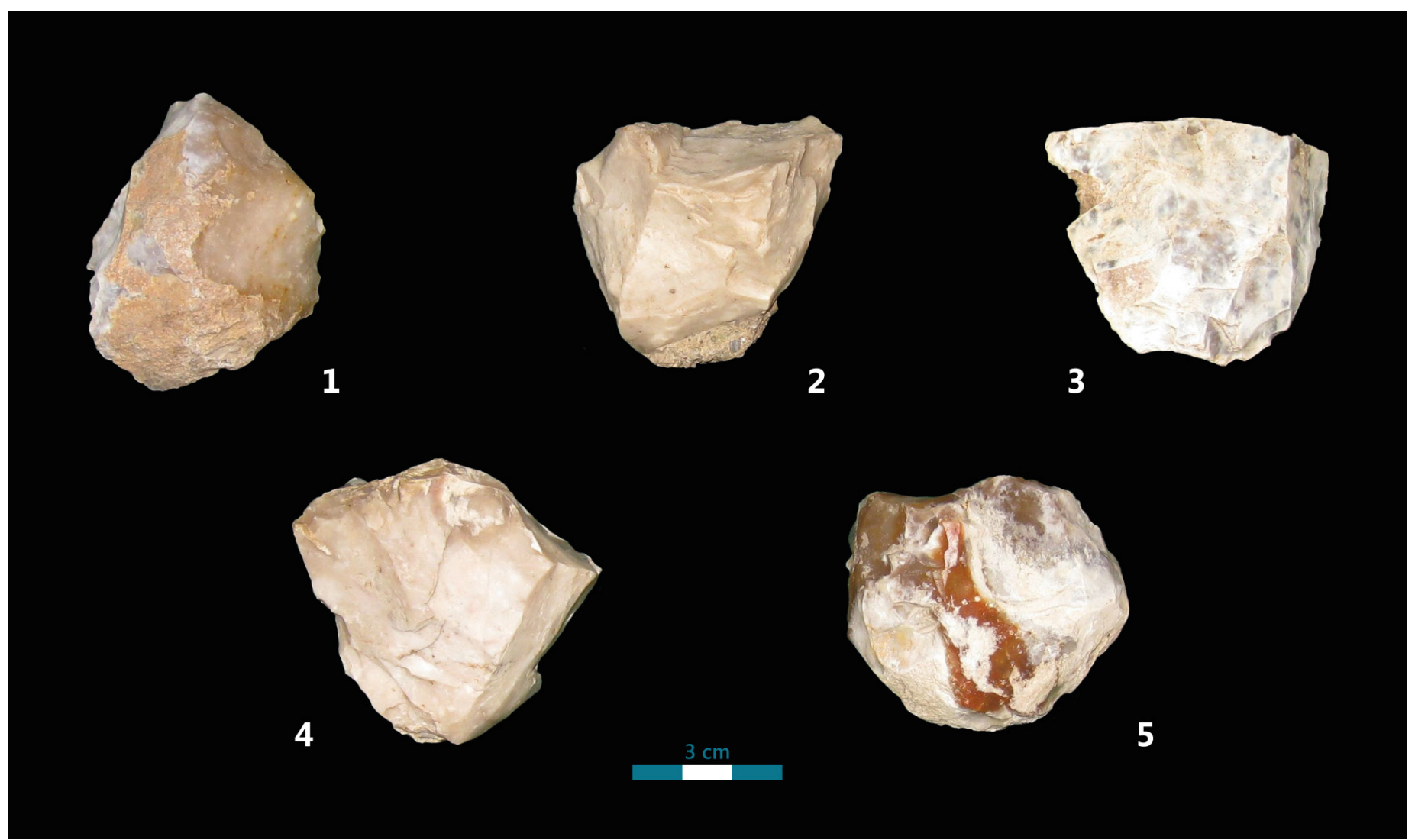

6. ábra. Magkövek. // Cores.

Fotók // Photos: Péntek A., Zandler K.

gyakran igen nagy mennyiségben előforduló távoli nyersanyag, a kvarcporfír hiányát illeti, azt gondoljuk, hogy a levélhegyes kultúráknak ebben a szakaszában a kvarcporfír valamilyen okból devalválód(hat)ott, esetleg nem is volt elérhető. Igen alacsony a kvarcporfír előfordulása DebercsényMogyorós lelőhely levéleszközös anyagában (Markó 2009) és a Bujákhoz közel eső Gyöngyös környéki levélhegyes lelőhelyeken is (Gutay 2007). Ez utóbbiak többnyire a helyi limnokvarcit előfordulásokon alapuló mühelyek. Hasonlóan alacsony a kvarcporfír aránya az Eger környéki lelőhelyeken is (Zandler 2006; 2012). A kvarcporfír szórványleletek formájában jelen van Ecseg-Sándor-hegy lelőhelyen (összesen $4 \mathrm{db}$ : 1 db kaparótöredék, 1-1 db szilánk és pattinték), ez a településfolt azonban nem volt továbbgyưjthető 2005 után.

A fiatalabb jellegű eszközök neolitikus benyomást keltenek. Kulturális besorolásuk kerámia hiányában legalábbis problematikus. Az eszközökben bizonyos kettôsség tapasztalható: a számos finoman kidolgozott csonkított darab mellett előfordulnak durvább eszközök is. Nem zárható ki tehát az sem, hogy maga a fiatalabb őskori anyag sem homogén.

A lelőhely jelentős részét jelenleg nem múvelik, ezért eredményes felszíni gyưjtés nem lehetséges. A gazos felszínen esetenként amorf nyersanyagdarabok találhatók ugyan kis számban, de releváns régészeti anyag előfordulása már nem valószínú. A paleolitikus anyag elsősorban 2001-2005 között, a művelés első éveiben került elő nagyobb mennyiségben, miután a területet mintegy 40-50 cm mélyen felszántották. További eredmények csak egy hitelesítő ásatástól várhatóak.
A lelőhelytől tovább haladva a földúton észak-északkeleti irányban a Bokri-hegy felé több helyen is található további fiatalabb őskori anyag (Szente \#1, \#3, \#4). Miután a terület nagy részét itt sem múvelik, nem állapítható meg bizonyosan, hogy paleolitikus anyag felbukkan-e máshol is. Érdekességként említhető meg még egy, a lelőhely felé vezető földúton talált szórványlelet. A lelőhelytől mintegy 300 m távolságra, a földrajzi leírásánál említett „zsákvölgy” közvetlen közelében, a földút jobb oldalán található piroxénandezit tufa feltárásokkal egyvonalban, a földút oldalából előkerült egy nagyméretü, kvarcit kettős kaparó. Bár a leletnek az ismertetett lelőhelyhez való kapcsolata nyilvánvalónak tûnik, a lelet megtalálási helyszíne - egy, a völgyfőt ellenőrző domináns stratégiai pozíció, „vadászles” - jelenleg nem alkalmas felszíni gyưjitésre.

Buják-Szente lelőhely és az említett Ecseg-Sándor-hegy lelőhely mellett mindenképpen érdemes lenne Buják-Rózsástetőt is figyelemmel kísérni, ahol $1 \mathrm{db}$ megmunkált radiolarit leletet, egy paleolitikus kaparót találtunk. A kiváló pattintási tulajdonsággal bíró táblás limnokvarcit előfordulása miatt itt minden bizonnyal további leletek előkerülése várható. Reményeink szerint a közeljövőben a Buják-Nádasd lelőhelyen és annak környékén is sikerül további, tipológiailag értelmezhető, és esetleg konkrét paleolitikus iparhoz kapcsolható régészeti anyagot találnunk. Reményeinket erősítheti az a tény is, hogy itt a lelőhelyhez közel, a Havas-hegy lábánál helyi limnokvarcit nyersanyag található. 


\section{Katalógus}

A hosszúságnál, szélességnél, vastagságnál zárójelben megadott értékek az aktuális méretet jelentik a törött darabok esetében.

\subsection{Vakarók}

Szilánkvakaró: hajógerinc alakú vakaró jellegû. Az előlap jobb oldalán kavicskéreg; az ívelt vakaróél meredek, közepén enyhén homorú az élmegújítás miatt. A hátlapon a bázis környékén részleges elvékonyítás, a bulbus oldalirányból eltávolítva, a talon sima. Radiolarit. 34×30×15 mm. Ltsz.: 1 .

Szilánkvakaró: ívelt vakaróél, a jobb oldaléle részlegesen retusált, a bal oldalél maga a magkőfelszín. A a bázis közelében „használati retus”. Talonja sima, az eszköz morfológiai és debitázstengelye eltérő. Radiolarit. 40×29×9 mm. Ltsz.: 2 .

Szilánkvakaró: kettős vagy szubcirkuláris vakaró. A vakaróélek íveltek, a proximális vakaróél elhasznált. A bal oldalélen használati nyomok, a jobb oldaléle finoman retusált, bulbusa nincsen. Túzkő. 35×28×9 mm. Ltsz.: 3 .

Szilánkvakaró: hajógerinc alakú vakaró jellegű. Ívelt vakaróéle meredek, többször megújított, középső részén a szilánk gerince miatt a megújítások során atipikus orr jött létre. Jobb oldaléle végig, a bal pedig részlegesen retusált, talonja preparált. Limnokvarcit. 43x27x15 mm. Ltsz.: 4.

Szilánkvakaró: munkaéle tört vonalú, csúcsos jellegú, így szegletes kaparóra emlékeztető. Bal oldaléle retusált, a bázis közelében törött. Jobb oldaléle ívelt, teljes hosszában retusált. Az előlap nagy részét zárványok borítják, a bulbus és a talon nem felismerhető. Limnokvarcit. 37x36x10 mm. Ltsz.: 5.

Szilánkvakaró: a vakaróél ívelt, az oldalélek is teljes hoszszukban retusáltak. A jobb oldalélen recens sérülés, a bázis kialakítása hegyes, csúcsos kaparóra emlékeztető. Nem kizárt, hogy ez a báziskialakítás a nyélbefoglalást szolgálta, a bulbust eltávolították. Limnokvarcit. 40x26x9 mm. Ltsz.: 6 .

Szilánkvakaró: átégett darab; a vakaróél és a jobb oldalél részben hiányzik, proximális vége hegyesedő. Limnokvarcit. (37) x(28)x12 mm. Ltsz.: 8 .

Szilánkvakaró: rövid, széles szilánkon készült. A szilánk debitázstengelye és az eszköz morfológiai tengelye merőleges egymásra. A vakaróél a jobb oldalélen lett kialakítva, a bal oldalélén zárványos kitöredezés. Limnokvarcit. 22x33x9 mm. Ltsz.: 9.

Szilánkvakaró: hajógerinc alakú vakaró jellegú. Az ívelt vakaróél jobb oldala és a bal oldalél a bázis közelében (feltehetően a fiatalabb őskorban) újraretusált, ennek következtében patinátlan. Limnokvarcit. 39x28x11 mm. Ltsz.: 10.

Szilánkvakaró: vaskos szilánkon készült eszköz. A vakaróél ívelt, a bal oldaléle teljes hosszában retusált. Az előlap közepén zárvány. Részleges hátlapi vékonyítás, bulbusát eltávolították. Limnokvarcit. 38x38x11 mm. Ltsz.: 11.
Szilánkvakaró: a disztális vége törött, a szilánk debitázstengelye és az eszköz morfológiai tengelye nem esik egybe. Limnokvarcit. (35)x34)x11 mm. Ltsz.: 25.

Szilánkvakaró: szépen, gondosan ívelt vakaróél. Bal oldaléle retusált, jobb oldaléle magkőperem. Limnokvarcit. 43×34x13 mm. Ltsz.: 26.

Szilánkvakaró: vaskos szilánkon készült eszköz. Az ívelt vakaróél és mindkét oldalél meredeken, lépcsősen retusált, megújított. Talonja sima. Limnokvarcit. 51x39x16 mm. Ltsz.: 41.

Szilánkvakaró: vaskos szilánkon készült eszköz. Vakaróéle ivelt, meredek, megújított. A bal oldalélen az előlap felől kivitelezett Clactonien-völgyelés, jobb oldaléle „használati retust" mutat. Bázisa törött, vagy csonkított. Talonja sima. Limnokvarcit. 47x39x19 mm. Ltsz.: 44.

Szilánkvakaró: az eszköz jobb oldala és a hátlap jelentős része a nyersanyag zárványos szerkezete folytán törött. A megközelítőleg ívelt vakaróél meredek, megújított. A talon facettált. Limnokvarcit. 48x(30)x(21) mm. Ltsz.: 52.

Atipikus szilánkvakaró: magkőtöredéken készült „gyaluszerü” eszköz. A megközelítőleg egyenes vakaróél meredek, megújított. Limnokvarcit. 37x35x15 mm. Ltsz.: 58.

Atipikus szilánkvakaró: enyhén balra hajló orros kialakítású darab, mindkét oldaléle meredeken retusált. Limnokvarcit. 35x20x19 mm. Ltsz.: 62 .

\subsection{Levéleszközök}

Levéleszköz: a hossztengelyre szimmetrikus, megközelítőleg plánkonvex keresztmetszetű, lekerekített bázisú levéleszköz. Disztális vége törött, a hátlapon, a bázis közelében a nyersanyag kvarcit kristályos belső szerkezete tárul fel. Limnokvarcit. 50x28x12 mm. Ltsz.: 30.

Levéleszköz: a hossztengelyre enyhén aszimmetrikus, plánkonvex keresztmetszetú, lekerekített bázisú, bal élén zegzugos lefutású, jobb élen hátlapi vékonyítású levéleszköz. Pattintási hiba miatt felhagyták. Limnokvarcit. 50x28x16 mm. Ltsz.: 32.

Levéleszköz töredéke: a hossztengelyre szimmetrikus, plánkonvex keresztmetszetű, lekerekített bázisú levéleszköz. Bal oldala a disztális vég közelében régi törést visel. Az előlap elnagyoltan megmunkált, a hátlap bal oldala vékonyított, a jobb oldalon zárványos a nyersanyaga. Bulbusát eltávolították. Limnokvarcit. (47)x(32)x12 mm. Ltsz.: 33.

Bifaciális levéleszköz: plánkonvex keresztmetszetű, a hossztengelyre aszimmetrikus. Szinte az előlap teljes felülete centripetálisan megmunkált. Az élek elnagyoltak, a hátlapon laposan retusáltak. Limnokvarcit. 53×36×12 mm. Ltsz.: 34.

Levélhegy töredéke: az erősen patinás felszín miatt nem állapítható meg egyértelmüen, de inkább disztális töredékről 
lehet szó. Paralelogramma keresztmetszetú, a hossztengelyre enyhén aszimmetrikus. A jobb oldalél az előlap felől finoman, a hátlap felól laposan retusált, a bal oldalél zegzugos lefutású. Limnokvarcit. (52)x36x16 mm. Ltsz.: 37.

\subsection{Bifaciális eszközök}

Bifaciálisan megmunkált eszköz proximális töredéke: paralelogramma keresztmetszetü. A bázisa vékonyított, enyhe völgyelésszerü kialakítással. Zavaros fehéres színű patinátlan nyersanyag. Kovakavics vagy tüzkő. (23)x(27)x(11) mm. Ltsz.: 15.

Bifaciálisan megmunkált eszköz töredéke: a tájolás nem állapítható meg. Az előlap gondosan megmunkált, az „U” alakú egybefüggő élszakasz lépcsősen retusált. Limnokvarcit. (28) x(28)x8 mm. Ltsz.: 17.

Bifaciális eszköz töredéke: egyik élén unifaciálisan, másik élén bifaciálisan retusált, szilánkon készült eszköz meziális töredéke. Limnokvarcit. (22)x36x6 mm. Ltsz.: 23.

Bifaciális élmegmunkálású eszköz töredéke: bal oldaléle ívelt, kaparószerúen retusált. A disztális vége részben törött. A jobb oldalélen friss sérülések láthatóak. Előlapján zárványos kitörés található. Limnokvarcit. 47x31x11 mm. Ltsz.: 27.

Bifaciális eszköz töredéke: hossztengelyre aszimmetrikus, plánkonvex keresztmetszetû, nyersanyaghiba miatt félbehagyott bifaciális eszköz töredéke. Limnokvarcit. (55)x42x18 mm. Ltsz.: 39.

Bifaciálisan megmunkált eszköz proximális töredéke: mindkét oldaléle zegzugos vonalú, bifaciálisan megmunkált. Bázisa csonkított, bulbusa nincsen. Disztális végén „frissebb”, nem patinás törés, amelyen retusált völgyelés található. Limnokvarcit. (26)x39x9 mm. Ltsz.: 47.

\subsection{Kaparók}

Szegletes kaparó: a szupport-szilánk proximális vége szándékosan törött. Mindkét oldaléle enyhén ívelt vonalúan lépcsősen retusált. A jobbra ferdén lejtő enyhén ívelt vonalú disztális élének a jobb oldalélhez közeli része megújított. A bal oldalél disztális vége a hátlapon részlegesen vékonyított. Limnokvarcit. 38x40x11 mm. Ltsz.: 12.

Ivelt élü kaparó töredéke: bal oldaléle retusált, disztális végén és jobb oldalélén új keletü törés. A hátlapon nagy fagyási kipattogzás. Limnokvarcit. (37)x26x7 mm. Ltsz.: 13.

Ívelt élü kaparó töredéke: vaskos szilánkon készült eszköz. Bal éle lépcsősen retusált, disztális és proximális vége valamint jobb éle törött. Limnokvarcit. (28)x(20)x11 mm. Ltsz.: 14.

Egyenes élú egyszerú kaparó töredéke: vékony szilánkon készült eszköz. Egyenes vonalú munkaél, disztális vége törött. Bázisa szándékosan törött. Limnokvarcit. (42)x27x6 mm. Ltsz.: 18.

Egyenes élü egyszerü kaparó töredéke: vaskos szilánkon készült eszköz. Lépcsősen retusált, tört vonalú munkaél, az élek találkozásánál hátlapi vékonyítás. Limnokvarcit. (41)x(21) x10 mm. Ltsz.: 19.

Bifaciális retusú kaparó: bal oldaléle az elő- és hátlap felől is finoman retusált. A szilánk bázisát a bulbussal együtt eltávolították. Az előlap jobb oldalán hosszanti repedés és zárvány a nyersanyagban. Limnokvarcit. 42x27x12 mm. Ltsz.: 20.

Ivelt élû egyszerú kaparó töredéke: kaparó lépcsősen retusált bal munkaélének meziális töredéke. Limnokvarcit. (33)x(31) x10 mm. Ltsz.: 24.

Ívelt élü egyszerü kaparó töredéke: egyik végén recens törés. Limnokvarcit. (41)x37x10 mm. Ltsz.: 28.

Kettôs kaparó töredéke: mindkét élén ívelt kettős kaparó. Mindkét oldalélén a bázis közelében ferdén csonkított, a hátlap részlegesen vékonyított. Limnokvarcit. (49)x35x11 mm. Ltsz.: 29.

Ívelt élü egyszerü kaparó töredéke: természetes hátú kaparó (racloir à dos naturel). Proximális vége törött, bal oldaléle az előlap felől lépcsősen retusált, a hátlapon kagylósan vékonyított. Radiolarit. (42)x34x10 mm. Ltsz.: 31.

Ivelt élü egyszerü kaparó töredéke: a bal oldaléle retusált, disztális vége régi törést visel, jobb oldalán recens törés. Előlapján a bázis közelében fagyási kipattogzás. Limnokvarcit. (50)x(43)x8 mm. Ltsz.: 35.

Kettôs kaparó töredéke: az előlap felszíne teljes egészében felületileg megmunkált, a hátlap részlegesen vékonyított. A bulbust eltávolították. A bal oldalél a hátlap felől vékonyított, a jobb oldalél disztális végén a hátlapon Prondnikleválasztás. Limnokvarcit. (46)x38x9 mm. Ltsz.: 36.

Egyenes élü egyszerü kaparó töredéke: természetes hátú kaparó (racloir à dos naturel). Nagyméretû, vaskos szilánkon készült eszköz. Disztális vége régi (esetleg szándékos) törést visel, bal oldaléle retusált (Quina-retus), jobb oldalán és az előlap disztális részének jobb felén a kiindulási gumó „ragyás” külső felszíne (kérge). Obszidián. (47)x47x12 mm. Ltsz.: 38.

Kettôs kaparó: bal oldalélének disztális vége egyenes vonalúan retusált, jobb oldaléle ívelt, teljes hosszában fél-Quina jellegüen retusált. Limnokvarcit. 57x39x15 mm. Ltsz.: 40.

Egyenes élü egyszerü kaparó: természetes hátú kaparó (racloir à dos naturel). Bal oldaléle Quina-retusú, disztális végének bal oldalán régi törés nyoma. Az eszköz vaskos jobb oldalán a magkőként szolgáló nyersanyag zárványai láthatóak. Limnokvarcit. 59x37x15 mm. Ltsz.: 42.

Szegletes kaparó: a kaparót a szupport-szilánk jobb oldalán alakították ki. A bal oldal vaskos, zárványokkal teli. Pontszerü talon, „nyelvecskével”. Limnokvarcit. 56×55x16 mm. Ltsz.: 45.

Kettôs kaparó töredéke: egyik oldaléle bifaciálisan, a másik oldaléle unifaciálisan, lépcsősen retusált. A hátlap részlegesen vékonyított. Limnokvarcit. 37x37x14 mm. Ltsz.: 46. 
Atipikus kettôs kaparó: az előlap nagy része repedezett, zárványos. Bal oldaléle és disztális vége ívelten retusált. Limnokvarcit. 37x41x15 mm. Ltsz.: 49.

Szegletes kaparó: vaskos szilánkon készült eszköz. Retusált bal oldalélén patinátlan, utólagos Clactonien-völgyelés található. A jobb oldalélnek a bázishoz közeli részén ugyancsak patinátlan Clactonien-völgyelés (vagy sérülés?). Limnokvarcit. 51x55x19 mm. Ltsz.: 50.

Atipikus kaparó: bal oldaléle enyhén ívelten retusált, a jobb oldaléle tört vonalúan, egyenes retusált élek által alkotott csúcsos kaparóra emlékeztetően megmunkált. Bázisa a hátlapon vékonyított, bulbusát eltávolították. Limnokvarcit. 42x50x13 mm. Ltsz.: 51.

Atipikus, ivelt élü egyszerü kaparó töredéke: magkőtöredéken vagy vaskos szilánkon készült eszköz. Retusált bal oldaléle enyhén ívelt vonalú, a darab disztális vége és jobb oldala törött. Viszonylag patinátlan. Limnokvarcit. (40)x(35)x18 mm. Ltsz.: 54 .

Kettôs kaparó töredéke: disztális vége és jobb oldala törött, a bal oldalél megmaradt disztális vége és a jobb oldalél megmaradt proximális vége finoman retusált. Limnokvarcit. (48)x(37)x12 mm. Ltsz.: 55.

Szegletes kaparó töredéke: (racloir déjeté très convexe), vaskos szilánkon készült eszköz. A szilánk debitázstengelye és az eszköz morfológiai tengelye nem állapítható meg egyértelmúen. Feltételezett proximális vége és jobb oldala törött. A kaparóél ívelt vonalú, a feltételezett bal oldaléle a bázis közelében ugyancsak retusált. Limnokvarcit. (26)x(48)x15 mm. Ltsz.: 56.

Atipikus kaparó: magkőtöredéken, vagy vaskos szilánkon készült eszköz. A darab tájolása nem állapítható meg. Egyik vége a magkő eredeti leütési felszíne, a másik vége törött. Az egyik él maradványa finoman retusált, a másik él kagylós retusálással bifaciálisan megmunkált. Limnokvarcit. (33) x(35)x15 mm. Ltsz.: 57.

Atipikus, ivelt élü egyszerü kaparó: természetes hátú kaparó (racloir à dos naturel). Vaskos kvarcit kavicsszeleten készült eszköz. Bal oldaléle enyhén ívelt vonalú, elnagyoltan retusált. Az eszköz jobb oldalán a kvarcit kavics eredeti kérge természetes hátat alkot. Kvarcit. 66×53×26 mm. Ltsz.: 66.

\subsection{Egyéb megmunkált darabok, eszközök}

Kombinált eszköz (bifaciális retusú kaparó+fúró): a középső részén található kisebb zárványtól eltekintve az elólap teljes felülete megmunkált. Mindkét oldaléle bifaciálisan retusált, bal oldaléle ívelt vonalú, lépcsősen retusált. Jobb oldaléle tört vonalú, ugyancsak lépcsősen retusált. Disztális vége csúcsos, a hátlap felől elvékonyított, a csúcs kétoldali retusált völgyeléssel, ill. vésőleválasztás által fúrószerűen kialakított. Limnokvarcit. 38x28x10 mm. Ltsz.: 7.

Retusált szilánk vagy ivelt élü kaparó töredéke: disztális vége régi törést visel, bal oldaléle retusált. Az előlap jobb oldalán proximális irányból csapott leválasztás negatívja látszik. Talonja pontszerü. Limnokvarcit. (33)x30x8 mm. Ltsz.: 16.

Eszköztöredék: lépcsősen retusált munkaél. Limnokvarcit. (33) $\mathrm{x}(22) \mathrm{x}(14) \mathrm{mm}$. Ltsz.: 21.

Retusált szilánk és (pszeudo-)vésô töredéke: jobb oldaléle retusált, proximális végén vésőleválasztás negatívja. Bázisa szándékosan törött. Limnokvarcit. (34)x31x4 mm. Ltsz.: 22.

Fúró: proximális vége mindkét lap felől kagylósan vékonyított (nyélbefoglaláshoz?). Disztális végén a hegy kétoldali völgyeléssel kialakított; bal oldaléle megközelítőleg egyenes vonalú, finoman retusált. Jobb oldalélének középső része kitörött, egyébként finoman retusált. Limnokvarcit. 60x(36) x16 mm. Ltsz.: 43.

Völgyelt eszköz: vaskos szilánkon készült eszköz. Disztális végét kéreg fedi, a bal oldalél bázis felőli része ívesen retusált. Jobb oldalélének bázishoz közeli része retusált, ill. völgyelt. Limnokvarcit. 44x37x17 mm. Ltsz.: 48.

Atipikus kombinált eszköz: a jobb oldalél részlegesen megmunkált, a disztális része retusált, proximális végén (a bázishoz közel) retusált völgyelés található. A megmunkált rész patináltsága elüt az előlap nagy részének patináltságától. Limnokvarcit. 39x41x14 mm. Ltsz.: 53.

Véső vagy pszeudo-vésô töredéke: a szupport penge vagy nyújtott szilánk. Jobb oldaléle törött, a bázis közelében vésőszerü kialakítással. Limnokvarcit. 59x(34)x11 mm. Ltsz.: 61.

\subsection{Meghatározhatatlan töredékek}

Az alábbi daraboknál a töredezettség miatt a méretek megadásának nincsen értelme.

2 db unifaciálisan megmunkált munkaél töredék: Limnokvarcit. Ltsz.: 59.-60.

7 db megmunkált eszköztöredék: Limnokvarcit. Ltsz.: 63.-69.

2 db megmunkált eszköztöredék: Radiolarit. Ltsz.: 70.-71.

\section{English summary}

According to the results of field work carried out in recent years, the palaeolithic occupation in the Cserhát Mountains was very intensive. Buják-Szente site is located on the margin of a plateau that rises $297 \mathrm{~m}$ above sea level, lying north of the village of Buják in the Eastern Cserhát Mountains. Near the site there is a "dead end valley". Other Middle Paleolithic or Early Upper Paleolithic sites are lying along or at the heads of "dead end valleys". We argue that the association between the sites and the valleys are related to hunting strategy.

Buják-Szente assemblage contains 1495 knapped stone artefacts. The most dominant raw material is the local limnic quartzite of Miocene postvolcanic activity. This raw material is common in Cserhát Mountains. In the vicinity of the site 
there is a specific tabular occurrence of extra fine quality. This limnic quartzite is very suitable for knapping. Other local raw materials like the andesite, chert and quartzite are represented only by a few pieces. Long distance raw materials, the Carpathian 1 type obsidian and the northern flint are also represented by a few pieces. There is a small amount of radiolarite of unknown origin.

In the assemblage there are 102 formal tools mostly made of the local limnic quarzite. The assemblage consists of two artifacts of two archaeological periods. These can be separated on typological basis to the Palaeolithic and to the Neolithic.

We classified 72 tools Palaeolithic. This is a non-Levallois flake-industry with by bifacial technology. Among the 72 formal tools we distinguished 5 fundamental tool categories. There are 17 end scrapers on flake (23.61\%). There is a raw material preference for limnic quartzite. Only 2 items were made of radiolarite and 1 of northern flint. Most of them resemble the pieces of the Moravian or Bavarian Szeletian. The lateral retouching, the ventral thinning of the proximal part and the eliminating of the bulb are relatively frequent. The Upper Palaeolithic types of end scrapers are represented only by 5 rather atypical pieces, there are 4 carinated and 1 nosed end scrapers.

The tool category of the leaf-shaped tools consists of 5 pieces (6.94\%), but only 1 broken piece could be interpreted as point. All were made of limnic quartzite. A common characteristic is the "wechselseitig gleichgerichtete Kantenbearbeitung" shaping strategy that is typical to Micoquian and known from the early Szeletian.

There are 6 pieces $(8.33 \%)$ in the category of the other bifacial tools which are broken and atypical. Only 1 piece was made of northern flint the other ones are of limnic quartzite.

The most numerous category is the side scrapers (24 pieces altogether - 34.72\%). Limnic quartzite dominates side scrapers; there are only 1 obsidian and 1 radiolarite. The side scrapers are relatively large, the biggest one has the measure of 59x37x15 mm. Most of them have simple straight working edge, but there are double, dejeté, and bifacial types. Their retouch is of Quina or semi-Quina type.

One piece has a characteristic of Prondnik-technique, which is typical to the Polish or German Micoquian industries ("Keilmessergruppe"). It is also present at some archaic Szeletian sites in Moravia such as Jezeřany I and II. This type was also found at Szécsénke-Kis-Ferenc-hegy site and Legénd-Rovnya.

The last tool category is the miscellaneous which contains 19 pieces (26.39\%). Besides an atypical borer-like tool there are 2 notched tools and a burin. There is a retouched flake or broken side scraper.

The Neolithic collection is a typical blade industry. It consists of 30 tools of varied type. There are end srcapers made on flake as well as made on blade, notched and denticulated tools, burins and retouched blades and microblades. The 41 pieces of cores of diverse stages belongs mainly to this industry. The tool assemblage could be attributed with the Lengyel Culture of Late Neolithic.

Due to the few number of tools, the artefacts collected from the surface are not suitable for a more detailed cultural classification. We consider the Palaeolithic material as relatively homogenous and belonging to a younger or developed phase of the Szeletian culture. The geological outcrops of the Szeletian felsitic porphyry are located 100-120 $\mathrm{km}$. In general this raw material is extraordinarily frequent at the Middle Palaeolithic sites of the Cserhát Mountains. But its ratio is very low in the assemblages with leaf-shaped tools at Debercsény-Mogyorós, in the environs of Gyöngyös and at all sites of the Eger region. Regarding the lack of this raw material at Buják-Szente site, we have the opinion that there may have been a particular devaluation of it in the late phase of our leaf-point industry.

\section{Irodalom}

Bogsch L. 1943. A Buják-Szirák közötti, illetve a Mátraszőlős környéki kövületlelőhelyek földtani viszonyai (Jelentés az 1940. évi felvételről). A Magyar királyi Földtani Intézet Évi Jelentése 1939-1940: 521-531.

Csongrádi-Balogh, É., Dobosi, V. T. 1995. Paleolithic settlement traces near Püspökhatvan. Folia Archaeologica 44:37-59.

Gutay, M. 2007. Régészeti lelóhelyek a Zagyva felsô-folyása mentén, Hatvan-Kisgombos és Pásztó között. Ôskôkori lelőhelyek a Mátra déli és délnyugati részén. Szakdolgozat, Budapest: Eötvös Loránd Tudományegyetem, kézirat.

Hámor, G. 1985. A Nógrád-Cserháti kutatási terület földtani viszonyai - Geology of the Nógrád-Cserháti area. Geologica hungarica Series geologica 22, Budapest: Magyar Állami Földtani Intézet.

Heinen, M., Beck, D. 1997. Ausgrabungen auf dem Szeletien-Fundplatz Zeitlarn, Lkr. Regensburg. Beiträge zur Archäologie in der Oberpfalz 1:71-88.

Hladíková, L. 2002. Szeletienská štípaná industrie z lokality Trboušany I (The szeletian chipped industry from the site Trboušany I). Acta Musei Moraviae Sci. Soc. 87/1-2:57-80.

Horváth, G. 2000. Nógrád-megye természetföldrajza. Budapest: Eötvös Loránd Tudományegyetem, kézirat.

Jöris, O. 2001. Der spätmittelpaläolithische Fundplatz Buhlen (Grabungen 1966-69) - Stratigraphie, Steinartefakte und Fauna des Oberen Fundplatzes. Bonn: Dr. Rudolf Habelt GmbH.

Markó, A., Péntek A. 2003-2004. Raw material procurement strategy on the palaeolithic site of Legénd Káldy-tanya (Cserhát Mountains, Northern Hungary). Praehistoria 4-5:165-177.

Markó, A. 2004. Újabb kőeszköz a galgagyörki Csonkás-hegyről. Ősrégészeti Levelek 6:10-12.

Markó, A. 2005. Limnokvarcit a Cserhát hegységben (Limnic quartzite in the Cserhát Mountains). Archeometriai Mühely 2(4):52-55.

Markó, A. 2007. Preliminary report on the excavations of the Middle Palaeolithic site Vanyarc - Szlovácka-dolina. Communicationes Archaeologicae Hungaricae 2007:5-18.

Markó, A. 2009. Levéleszközös leletegyüttes Debercsényből (Leafshaped industry from Debercsény). Archaeologiai Értesítô 134:155163. https://doi.org/10.1556/ArchErt.134.2009.9

Markó, A. 2012. Középsô-paleolitikus leletegyüttesek Vanyarc környékén. 
Doktori disszertáció, Budapest: Eötvös Loránd Tudományegyetem, kézirat.

Markó, A., Péntek, A., Béres, S. 2002. Chipped stone assemblages from the environs of Galgagyörk (Northern Hungary). Praehistoria 3:245-257.

Noszky, J. 1914. A Cserhát középső részének földtani viszonyai. (Jelentés az 1913. évi földtani felvételekről). A Magyar királyi Földtani Intézet Évi Jelentései 1913:305-325.

Noszky, J. 1923. A Zagyva völgy és környékének geológiai és fejlődéstörténeti vázlata. Annales Musei Nationalis Hungarici 20:60-72.

Noszky, J. 1940. A Cserháthegység földtani viszonyai. Magyar tájak földtani leírása III - Das Cserhát-Gebirge. Geologische Beschreibung Ungarischer Landschaften III. Budapest: Magyar királyi Földtani Intézet.

Oliva, M. 1979. Die Herkunft des Szeletien im Lichte neuer Funde von Jezeřany. Acta Musei Moraviae Sci. Soc. 64:45-78.

Péntek, A., Zandler, K. 2013. Nyíltszíni Szeletien telep Szécsénke-KisFerenc-hegyen. Litikum 1:36-49.

Péntek, A., Zandler, K. sajtó alatt. Nyíltszíni levéleszközös telep Legénd-Rovnyán. Neograd - A Nógrád Megyei Múzeumok Évkönyve.

Schönweiss, W., Werner, H.-J. 1986. Ein Fundplatz des Szeletien in Zeitlarn bei Regensburg. Archäologisches Korrespondenzblatt 16/1:7-12.

Szentes, F. 1943. Aszód távolabbi környékének földtani viszonyai. Magyar tájak földtani leírása IV. - Die weitere Umgebung von Aszód. Geologische Beschreibung Ungarischer Landschaften IV. Budapest: Magyar királyi Földtani Intézet.

T. Biró, K. 1981. A Kárpát-medencei obszidiánok vizsgálata (Archaeological study of the Carpathian obsidians). Archaeologiai Értesitő 108:194-205.

T. Biró, K. 1984. Őskőkori és őskori pattintott kőeszközeink nyersanyagának forrásai (Sources of Lithic Raw Materials for Chipped Implements in Hungary). Archaeologiai Értesitô 111:42-52.

T. Biró, K. 2011. Magyarországi kovakőzetek kutatása (Investigations of siliceous rocks in Hungary). Archeometriai Mühely 8(3):211-218.

T. Dobosi, V. 1978. A pattintott kőeszközök nyersanyagáról (Über das Rohmaterial der retuschierten Steingeräte). Folia Archaeologica 29:7-19.

Valoch, K. 1967. Die altsteinzeitlichen Stationen im Raum von Ondratice in Mähren. Acta Musei Moraviae Sci. Soc. 52:5-45.

Valoch, K. 1973. Neslovice, eine bedeutende Oberflächenfundstelle des Szeletien in Mähren. Acta Musei Moraviae Sci. Soc. 58:5-76.

Valoch, K., Kočí, A., Mook, W. G., Opravil, E., van der Plicht, J., Smolíková, L., Weber, Z. 1993. Vedrovice V, eine Siedlung des Szeletien in Südmähren. Quartär 43-44:7-93.

Zandler, K. 2006. Paleolit lelôhelyek Eger környékén. Szakdolgozat, Budapest:. Eötvös Loránd Tudományegyetem, kézirat.

Zandler, K. 2010. Paleolit telep Hont-Csitáron (A palaeolithic site at Hont-Csitár). In: Guba, Sz., Tankó, K. (szerk.): „,Régrôl kell kezdenünk..." Studia Archaeologica in honorem Pauli Patay. Régészeti tanulmányok Nógrád megyéból Patay Pál tiszteletére. Szécsény, 23-49.

Zandler, K. 2012. A paleolitikum kőiparai Eger környékén. Gesta 11:3-54. 